TEME, г. XLIV, бр. 1, јануар - март 2020, стр. 121-138

Прегледни рад $\mathrm{https} / /$ doi.org/10.22190/TEME191223012M

Примљено: 23. 12. 2019.

Ревидирана верзија: 4. 2. 2020.

Одобрено за штампу: 20. 2. 2020.

\title{
CONTEMPORARY PSYCHOANALYSIS - PERSPECTIVES AND THE SCIENTIFIC STATUS
}

\author{
Jana Milić* \\ University of Niš, Faculty of Philosophy, Niš, Serbia \\ *Doctoral candidate \\ jana.milic.psihologija@gmail.com
}

\begin{abstract}
This paper is actually a review of the status of psychoanalysis versus science. The lack of articles in contemporary discussions, and the absence of the topic of psychoanalysis suggests that there is less interest in the given topic. The impression is that the therapist who has the function of a patient does not have the time for other means of research and work. This supports the contemporary views that a therapist is, figuratively speaking, married to therapy and, therefore, cannot do anything for its sake. Strong criticism persisting even today is that addressed to Freud (in reference to relational psychoanalysis), arguing that he could not even bear to be seen as a warm and gentle figure by his patients. He is even known to have sat in a chair behind the headrest of the sofa used by the patient, in order to avoid looking the patients in the eyes, claiming it to be bothersome. The third century of the existence of psychoanalysis seems to be the time of questioning of whether the interest in this topic is disappearing. The corpus of psychoanalysis has been implemented throughout the 20th century. The general attitudes are that the analytical method has to change. Contemporary society wants quick results because the contemporary individual has little time. Psychoanalysis has always preferred the quiet, which now is a bad strategy, because very little has been done about its visibility and promotion.
\end{abstract}

Key words: unconsciousness, the scientific status of psychoanalysis, contemporary, approaches, the visibility of psychoanalysis.

\section{САВРЕМЕНА ПСИХОАНАЛИЗА - ПЕРСПЕКТИВЕ И НАУЧНИ СТАТУС}

\section{Апстракт}

Овај рад је приказ статуса психоанализе, као теорије и терапије у поређењу са науком. У актуелној литератури цитирају се референце старијег датума, што наводи на размишљање да понестаје интересовања за ову тему. Стиче се утисак да је терапеут само у функцији пацијента и нема времена за друге облике истраживања и рада. То иде у прилог савременим гледиштима да је терапеут посвећен терапији, те због ње саме не може да дела у корист ње. Једна од највећих замерки која се упућује 
Фројду (унутар релационе психоанализе) јесте та што он није могао да поднесе да га пацијенти доживљавају као топлу и нежну фигуру. Фројд је чак седео на столици крај узглавља дивана на коме је лежао пацијент како не би морао да га гледа у очи, тврдећи да га то замара. Питање које се поставља у трећем веку постојања психоанализе јесте да ли понестаје интересовање за ову тему. Током двадесетог века утемељивао се корпус психоанализе. Општи став је да аналитички метод мора да се мења. Савремено друштво жели брзе резултате јер савремени човек пати од недостатка времена. Психоанализи је увек била дража тишина, што је сада погрешна стратегиja, јер је веома мало учињено за њену видљивост, али и промоцију.

Кључне речи: несвесно, научни статус психоанализе, савремени приступи, видљивост психоанализе.

\section{INTRODUCTION}

The analyst is not the supreme arbitrator of truth. What is important is the process. The point is not set on the acquisition of (psychoanalytic, per se) truth, the truth about the unconscious. The process is important (Jevremović, 2005).

The historical development of psychoanalysis is bound to Freud who named it in 1896. He began creating the corpus of theoretical concepts and practical methods which only grew in the $20^{\text {th }}$ century, due to the great number of its seriously dedicated authors and followers.

According to Zlopaša (2015), psychoanalysis is the oldest branch of psychotherapy which made possible the development of other fields, but changed itself, as well, due to internal and external factors. The internal factors refer to the accumulation of experience, failures, adaptation to pathology, the critical reconsideration and the changes in modern science. The external factors pertain to the period during which some other personality entities were being developed, hence their influence on the changes and the general scientific trends in the humanities. Commenting further, the author says that the issue of identifying the whole corpus of psychoanalysis with Freud's charismatic personality is a big problem and, at times, hinders the further growth of psychoanalysis. It often seems necessary to reiterate that psychoanalysis has not stopped developing after Freud, and that it does not currently aspire to remain within Freud's framework. The founder of psychoanalysis is Freud, but after Freud, psychoanalysis experienced its new beginning and further development.

Jevremović (2005) states that psychoanalysis is a matter of experience, always concrete experience, the experience of a concrete subject. The author speaks about experience in theory, as well as experience in practice, analytical practice - an inevitable paradoxical crash. Furthermore, he argues the direction of where high speculations lead, which inevitably coincide with the sphere of concrete, preverbal, infantile, phantasmatic, pre-linguistic and proto-linguistic, and the bodily. The range includes preverbal and secondary process thoughts, but the unthinkable as well. Then the author sets the focus on the unconscious, irrational, possible 
madness (i.e. primary process) until it penetrates the subjective, defined as the important truth in the psychoanalysis. In doing so, he draws attention to the fact that psychoanalysis is an area of the mind that is very specific and delicate. It does not have the character of universality, but it has the character of repetition.

In Damjanović (2015), we see an interpretation according to which Wittgenstein challenged the acceptability of Freud's theory and called it "skillful" and "cunning". According to him, Wittgenstein does not consider that Freud created something revolutionary and brilliant, and basically, the unconscious for him is not a discovery. Following this line of thought, Freud is but a creator of a new mythology and a new conceptual framework, however he is neither the creator nor finder of any new regions of the soul. What Freud claims for the unconscious seems scientific (empirical hypothesis), but is actually only the medium for thought representation.

Other Wittgenstein attitudes towards psychoanalysis question the methodology and its sense exploring and criticizing its methodology. Psychoanalysis is considered in terms of the mental space through the paradigm of the unconscious and free associations, which present the symbol and show the battle of the urges in an individual. Thus, according to this philosopher: "Undertaking psychoanalysis is somewhat similar to eating from the tree of knowledge. Knowledge, which we gain in this manner, confronts us with new ethical issues; And nothing more" (Jandrić, 2017, p. 75-91).

Wittgenstein questions the whole concept of psychoanalysis. In the same text about the "Blue Book" Jandric cites the following lines: "The idea that unconscious thoughts exist caused revolt in a large number of people. Others, however, said they were not right when supposing there are only conscious thoughts and that psychoanalysis revealed unconscious thoughts. Those who object the unconscious thoughts have not seen they have not objected the newly found psychological reactions, but the way they have been described" (Jandrić, 2017, p.75-91)

We will approach the consideration of the contemporary psychoanalysis from the perspective of science and pseudoscience. Psychoanalysis has already stepped into the third century of its existence, and there is a large number of research and publications which are referential and appreciated in science. It is frustrating, as always, how much material there is and how much cannot be said. Works and attitudes will be cited from the popular scene of psychoanalysis and psychodynamics from the experience of psychoanalytical authors of the epistemological, psychological, philosophical, scientific models in the period of three centuries. Currently there are referential authors, such as Stern, Fonagy, Gabard and Bornstein.

Sandler et al. (1998) saw contemporary psychoanalysis as a tripartite model or as the so-called "three box model." Psychoanalysis is a research method that assesses the growth of cognitive capacity and the expansion of 
emotional learning about oneself and people, which is the direct effect of therapeutic work.

\section{A LOOK BACK TO PSYCHOANALYSIS IN THE $20^{\text {th }}$ CENTURY}

It takes too long. Modern psychoanalysts are aware that the analytical method must change somewhat, because contemporary society is looking for quick results and contemporary individual has little time. In standard psychoanalysis, it is not always possible to achieve the goal of rapid change, because personality changes very slowly and insights are solidified over the years. In short analytical psychotherapy, existentialistoriented, state-funded groups, many are expected to have faster results (Jevremović, 2010; Jalom, 2011).

Psychoanalysts have a hard time writing. It is interesting that older references are often cited in contemporary literature, which leads one to think whether there is a lack of interest in this topic. Sometimes the therapist seems to be in the patient's function only, and that the method itself is in isolation Psychoanalysis has always preferred silence in that sense, which is not an effective strategy for its popularization nowadays. Observing the modern trend of psychoanalysis, two directions are observed:

- One for reconstruction;

- And the other for nomothetic projects to provide a solid basis for exploring scientific evidence.

There are few articles lately dealing with this topic. Fonagy \& Target (1997) conclude that psychoanalytic practice has deep limitations as a form of research, but that psychoanalytic theory can nevertheless be observed. In addition to that, " "modern science is almost exclusively interdisciplinary.

In fact, in the past 15-20 years, the field of neuroscience has been wide open with an adequate understanding of the determinants of development and adaptation. Fonagy (2003) believes that it is the right place for research and for brain function and expression of genetic potential. A number of studies have already suggested that the impact of psychotherapy can be seen in the changes in brain activity, using brain imaging techniques. "Clearly, the discipline can no longer exist on its own. Creating an analyst is an extremely long process. In order to be taken seriously, psychoanalysis, as a scientific study of the mind, must be included in systematic laboratory studies, epidemiological research, or qualitative research in the social sciences" (Fonagy, 2003, p. 73).

Considering Michel's opinion, Fonagy (2003) says that no experiment or set of experiments will ever serve as an arbitrary opinion of something as complex and resilient as psychoanalytic theory, but directs the strategy of modernizing the method of psychoanalysis, and states that "our goal should 
be to help move psychoanalysis towards science" (Fonagy, 2003, str. 74). The strategy advocates:

- Reinforcing the evidence base of psychoanalysis by adopting additional collection methods;

- Changing the logic of psychoanalytic discourse from its overreliance on rhetoric and global constructs. This means adjusting the use of specific constructs that enable cumulative data collection;

- Revising certain deficiencies in psychoanalytic scientific reasoning, especially where failure falls into consideration of alternative observations;

- Isolating psychoanalysis should be replaced by active collaboration with other mental health disciplines,

- a rapidly evolving "chain of knowledge" directed at different levels of studying the relationship between brain and behavior, that this may be the only way to preserve the hard-won insights of psychoanalysis.

Paul Stepansky dealt with the history of psychological work and psychoanalysis in particular. Dimitrijević (2011, str. 206) refers to Stepansky's efforts to apply the scientific language, in order "to change things in psychoanalysis and move it towards science."

Stepansky has been ubiquitous in educating psychoanalysts for the last three decades. He was the editor-in-chief of The Analytic Press journal, which was once the most important ones, and the only one in America. The analytic journal has set the highest standard for rigorous scientific and clinical case presentation. In discussing the survival of psychoanalysis, he concludes that there are only two paths:

- communicating with the scientific fields and applied fields as a nurturing trend of association with psychotherapy, and

- Openness towards other professions.

Stepansky believes that the recovery of psychoanalysis would be truly useful to society and science on the whole. The failure to observe his argument, may cause a stagnancy in the future development of psychoanalysis.

Stepansky says: "The survival of a profession in a foreseeable future lies behind a couch and out of the office" (according Dimitrijević, 2011, pp. 312). Following this line of thought, Stepansky warns us of the marginalization and fragmentation within contemporary American psychoanalysis that would need to be modernized. Most psychoanalysts can agree on basic analytical facts, but serious problems arise at the level of their interpretation. At one very important moment in psychoanalysis and psychiatry, one can see that there was a great connection. Psychoanalysis was technically established in accordance with the patient's disorder and the established duration in the treatment even with the most serious disorders. 
Paris (2017), while giving a comment on the connection between psychiatric and clinical method, considers the possibility of exploring the evidence. Is the psychoanalytical treatment based on evidence? Can psychiatry and psychotherapy be of use to one another? Answering these questions, he says that: "modern medicine and psychiatry expect all kinds of therapy to be supported by evidence. Psychoanalysts claimed it to be a science but did not succeed in operationalizing its hypotheses therefore the intellectual method of psychoanalysis is more similar to the humanities. In Britain, the humanities can have their dynamic guidance experts modeled while accepting significant deviation from the psychoanalytic conceptualization" (Paris, 2017, p. 321).

The attempt to connect psychoanalysis to science and finally stand under a psychiatric umbrella relied on a hermeneutical way of thinking that focuses on meaningful interpretations of the phenomenon rather than empirical testing of the hypotheses and observations. This is sometimes completely impossible in psychoanalytic methodology, but there is a tendency to find a nomothetic model that would rely on a non-existent scientific corpus. Further, Paris (2017) says that Mark Solms, a South African neuropsychologist, the founder of neuro-psychoanalysis, suggested using neuro-imaging to confirm analytical theories. His key idea is that subjective experience and the unconscious mind can be viewed through neuro-imaging. However, Paris, reminds us that brain processes cannot be seen on brain imaging before they are brought to consciousness. Hereby, neuro-dimensional validation of Freud's model of the unconscious cannot be explicitly proved. The correspondences observed are superficial and hardly support the complex edifice of psychoanalytic theory.

The conclusions that Paris (2017) reaches are quoted from an article so they are presented in the paper as a proposition that:

- Analysis has been separated from psychiatry and psychology and that their method is applied in independent institutes;

- A method can last only if it is ready to reform its structure as a separate discipline and to join the academy and the clinical science;

- Regardless of the limitations, psychoanalysis has left a great heritage to psychiatry;

- It taught generations of psychiatrists how to understand life histories and to carefully listen to what patients say;

- In an era dominated by neurosciences, diagnostic control lists and psychopharmacology, we have to find a way to keep psychoanalysis, whose basic terms came from Freud's work, and find their place in the science of psychiatry as well.

Dimitrijević (2015) states that the psychiatric path was also difficult, so the birth of scientific psychiatry and what we now call clinical psychiatry took place in the short period between the last decade of the eighteenth century and the 1820 . Everything that happened before that 
period - every description, diagnosis and therapy - was considered prescientific, outdated, and, in a way, worthless.

Dimitrijević, gives the argument that the first steps and roots of modern psychiatry began in England in the early modern period, so that in the field of mental health care modern continuity has been achieved. Then he says that the similarities between contemporary psychopathology and that of early modern England are striking. The concepts of possession and exorcism have been overturned, but we are still discussing the relationship between psychological and "external" factors in psychopathology. The mental disorders we encounter in our clinical practices were described four centuries ago. The public experience of the mentally ill is more affirmative than it used to be, but in the last five decades the stigma has been steadily increasing. Our approaches to treatment are not as bizarre as they used to be, but their effectiveness is far from perfect. If, however, we want to continue to improve, it may be important to remain aware of the continuity and roots of contemporary psychopathology that spans at least four and a half centuries (Dimitrijević, 2015).

A complex representation like this one reaches the existential foundations of psychiatry, i.e. brings to us to rethink the concept. And the path taken by psychiatry and psychoanalysis seems to be related primarily to an in-depth approach to understanding the problem, and that the question of why determining topography was shorter than the question of how, which determined phenomenology as a competent addition to understanding mental illnesses.

\section{THE PERSPECTIVES OF CONTEMPORARY PSYCHOANALYSIS}

In the world of science, Jalom says that psychologists, psychiatrists and psychotherapists are the intellectual elite, e.g. Jalom (2011). However, it is not rare that a patient in therapy and a psychiatric patient are equally stigmatized just like a psychotherapist and a psychiatrist.

Nowadays, relational psychoanalysis is becoming a common topic.

The official portal of the Croatian Psychoanalytic Society presents a few contemporary modalities of the method of psychoanalysis: "Relational (interpersonal) psychoanalysis, as the approach by the founder, Steven Mitchell (1946-2000), in the United States, rejected Freud's biologically entrenched theory of urge, suggested a theory of interpersonal conflict that combines real, thoughtful, and imagined interactions with significant others. Also, Psychoanalysis is then made to explore these patterns and confront with what is spontaneously and authentically co-opted in the psychoanalytic setting between the analyst and the patient" (www.hpsg.hr).

In addition, Belgrade Psychoanalytic Society (2018) emphasizes that: "Adhering to the golden rule of non-directionality and the rule of directing our attention to the actual surface of what the analysis provides 
us has made it possible to identify the most important phenomenon that occurs during psychoanalysis, and that is transfer" (www.bps.org.rs).

"The psychoanalytic method is considered to be a specific research method in the field of the human psyche and the unconscious. Today there are modifications of the psychoanalytic method which are used in the observation of the psychoanalytical effects, as well as the understanding of the process of change as a whole which is urged by psychoanalysis, either with clients or psychoanalysts)." (www.bps.org.rs/psihoanaliza)

Both the Serbian and Croatian schools were being greatly developed in the $20^{\text {th }}$ century. Both schools follow the current trends of psychoanalysis.

At the end of the 20th century great changes occurred in psychoanalysis in understanding the disorders of the personality structures, the mode of intervention, the counter-transfer, shaping according to the needs of the patient in technology, while the basis of instinctive theory also underwent some changes. So we distinguish a few practitioners from the classical Freudian psychoanalysis, the psychoanalysis of Klein, the selfobject theories to the interpersonal and intersubjective approaches. Therefore, there are several branches of the psychodynamic approach starting from the classic Freudian psychoanalysis, Kleinian psychoanalysis, self-object theories to the inter-subjective approaches.

The ultimate domain in psychoanalysis is the interpretation of dreams. As an imperial journey into the unconscious, it will undermine what made psychoanalysis indebted to science. Aron (1989, p. 79) claims that the basic approach in dream interpretation has changed: "For Freudians the key question is: what does it actually means? For interpersonalists the question is: what is happening here?"

"The interpretation of dreams, in the traditional sense, does not play a big role in the work of most interpersonal analysts. Not that dreams were ignored, but that there was no attempt to decipher. They are treated as communication, not puzzles, so the analyst asks what the dream says, not what it means. The free association method seems ideally suited to the purpose of excavating buried, hidden, and covered up latent content. But where the classic model encourages to emerge, beneath the disjointed, "analyzing," deciphering, manifest appearance, the interpersonal model seeks an expansion of experience by carefully focusing on the surface. The inter-personalist holds the magnifying glass across the surface in an attempt to see the subtlest experiences. We have seen various revisionist interventions with focus on the manifestation of content" (Aron, 1989, p. 73).

Further on, Aron (1989) says that dreams are specific in the clinical situation, especially because they lie as stories on the optimal distance between the everyday future and worry on one side, and the unconscious fantasy, autistic, indescribable thoughts and chaotic images, on the other. Conversing about a dream is organized, transferable, descriptive and to a great extent cohesive and coherent. Still, dreams are also our most striking communications. 
As Aron notes: „Together it connects the underworld of our desires and its integration with the rest of our autobiography results in further consolidation. Dreams, which may seem very trivial, provide a distance that allows one to explore the most serious problems. However, even the most difficult questions, when approached through the dream story, can be creatively worked on and played into, and thus give a sense of hope" (Aron, 1989, p. 125).

Many great $20^{\text {th }}$ century scientists fought to find the model for psychoanalytical method between nomothetic and idiographic research. For example, Bornstein (2001) says that a conceptual framework represents an aggregate of proximal rules for the construction of nomothetic research for testing psychoanalytic hypotheses, especially because psychoanalytic method is idiographic in nature. It is also important to make wider comprehensive principles which can better nomothetic research of psychoanalysis through recognizing the unique possibilities and challenges in psychoanalytic data. He describes 5 such principles:

"Principle 1: Incorporate each psychodynamic hypothesis into concepts with other aspects of psychoanalytic theory. Nomothetic psychoanalysis provides an opportunity for psychoanalytic researchers to pay greater attention to external facts where psychoanalytic attitudes and constructs are consistent with the principles and findings of other scientific fields;

Principle 2: Recognize that certain types of data cannot be obtained in the laboratory, and that certain types of data cannot be obtained in the consultation room;

Principle 3: Systematize guidelines for the collection and reporting of idiographic psychoanalytic data;

Principle 4: Use similar outcome measures in idiographic and nomothetic studies;

Principle 5: Pay special attention to variance indicators in nomothetic research" (Bornstein, 2001, p. 5).

In addition, he symbolically defines the following 7 deadly sins:

1. Insular communication in a narrow circle of like-minded;

2. Imprecision (concepts supported by empirical evidence are not separated from the ones which are not);

3. Loss of interest (disinterest for a different opinion) leads to exclusion and indifference to outer experience;

4. Unimportance, irrelevance of psychoanalysis in a scientific community is, for the most part, a consequence of psychoanalysts unrecognizing such a status. They do not recognize the marginalization of their theory and do nothing about it;

5. Inefficiency, extensive theoretical background and the longevity of a psychotherapeutic treatment even then when it is not necessary; 
6. Vagueness makes a theory unfit for empirical check hence excluding theoretical progress and degrades work both in theory and psychotherapy, unwillingness to acknowledge the problem and work on it;

7. Arrogance (a closed system supports separation from other circles, ideas, while the power of authority threatens every novelty, gains rigid characteristics (Bornstein, 2001, pp. 5-9).

According to Bornstein there are three scenarios that could save psychoanalysis from "illness" in metaphor.

"Scenario 1: Implement heroic measures to save the patient through a shift towards a major effort in research activities and empirical evidence of psychoanalysis concepts with a move toward integrative approaches that are in contact with medicine and general psychology.

Scenario 2: Let psychoanalysis die and then donate organs, or Let her concepts survive in contact with other directions. So, psychoanalysis and other directions could survive, as it has already been confirmed that many parts of psychoanalytic theory and concepts have survived assimilation and involvement in empirical and clinical research.

Scenario 3: Bury the body and pray for reincarnation, or, rejection and renunciation of psychoanalysis as it is today in order for its useful parts to undergo reality checks and survive. Certain concepts of psychoanalysis are already deeply rooted in general psychology and the social sciences, so it is certain that some other useful concepts might have such a fate" (Bornstein, 2001, pp. 10).

Accordingly, Bornstein (2001, pp. 15) considers psychoanalysis to be a: method of treatment, "and not only a theoretical science, has to provide empirical evidence on therapeutic treatment efficiency, to undergo transformations, while heading to new ideas and knowledge, to continuously starts debates inside a psychoanalytic community, to come closer to nomothetic scientific method, so as not to remain outdated provocative theory which is dying."

The possibility to set both biological and psychological - social base of psychoanalysis through neuroscience and nomothetic research is nowadays discussed.

An introduction to Bornstein's (2005) consideration of various resuscitation strategies for bringing psychoanalysis to life, states that the marginalized state of contemporary psychoanalysis is partly due to psychoanalysts and their willingness to keep their ideas silent from the credibility of theorists and researchers. This is, in fact, a revision of his earlier proposal that it is necessary to separate psychoanalysis as a discipline from contemporary science and psychology.

With the suggestion of a remedy reflected in the repair and movement and dynamics of twentieth-century psychoanalysis in its most basic form, Bornstein (2007) emphasizes the following three steps. 
- Step 1: to enable an audit and repetition;

- Step 2: to create an empirical database;

- Step 3: to recognize and parallel psychotherapy methods.

The consequence of this would be the reintegration and association to other methods. What would significantly increase the scientific value of psychoanalysis in addition to nomothetic and ideographic is the metaanalytic research. Bornstein (2007) says that meta-analytic techniques have a long history in psychology, and can simply connect with the proportions of the studies, which are statistically important. Meta-analytic techniques enable researchers to estimate the influence of mitigating the variables of the phenomenon in question, even if some of the variables are different in studies (not from within). When the techniques of neuropsychological evaluation become central in the testing and verification of the fixation of psychoanalytical ideas, we will come to a full circle, Freud's first outlines of psychoanalysis were derived from biological principles, as well as psychological ones, and much of his early urge model was framed by the language of $19^{\text {th }}$ century physiology.

Postmodern science offers various possibilities for reconnection of psychoanalysis to psychology. In the near future, psychoanalysis needs to regain even those ideas co-opted by other disciplines and connect to those very same disciplines for empirical inspiration (Wallerstein, 2009). The complexity of these questions should be researched at large, definitely even semantically, as methodologically and essentially, by applying qualitative (idiographic) and quantitative (nomothetic) research methodologies.

Some theoretical attitudes in the Serbian scene regard the present moment as unsuitable for the preservation of the classical long psychoanalysis, which is partly conditioned by the social moment itself.

The view of Jevremović (2010) is quite interesting because he really manages to connect history, philosophy, theology, metaphysics and psychotherapy. Jevremovic asked the question of how we understand psychoanalysis throughout his work. We cannot be indifferent to whether we consider psychotherapy (theory) and exercise as a vocation or as a skill technique. If psychotherapy is a mere skill, i.e. a technique, then it has market value. Modern society is market oriented. Psychoanalysis is therefore impaired because it is limited by the demands of contemporary society, which wants faster results and an immediate solution The author considers there are many strongholds in which psychoanalysis has proven to be a science. The goals of psychoanalysis need to be retained because they give it scientific meaning.

Zlopaša (2015) believes that any critique of psychoanalysis would require prior understanding of the process and its therapeutic goals. In further elaboration on Freud's thoughts, Zlopaša says: "Freud boldly, sometimes recklessly, entered the field of anthropology, evolution, culture and art, group and social dynamics... At the same time he feared the 
medicalization of psychoanalysis, which would make it a transient trend in the field of psychiatry. So, he tried to chart a course of psychoanalysis through the strait of 'Scile and Haribde' of medicine and philosophy, occasionally relying on both sides without allowing any of them to be too drawn to him, which would mark the loss of an independent path of development. The Freudian unconscious, they prepare and organize our experience before they reach consciousness" (Zlopaša, 2015, pp. 57).

This article also focuses on the neurosciences that are known to confirm the complexity of the neural processes and are trans-material entities that underlie the psychic life, which is indeed a facsimile role of the CNS. Most of the processes of evaluation and emotional coloring take place on an unconscious plane, with only a portion being finely cognitively processed in the form of conscious thoughts. Zlopaša (2015) goes on to consider that the hemispheric specialization and function of the right hemisphere have deep links with the physiological determination of the notion of the unconscious. He remarks that this also opens the question of the terminology of the unconscious. Freud did not invent it unconsciously, nor could he find it as some material, external, biological artifact. It really touches both neuroscience and physiology. Measurements are not possible yet, but the evaluations of clinical improvements to patients are still possible.

In contemporary neurology it is known that most of the processes of evaluating the emotional coloring go on the unconscious plane and that only a part is finally processed cognitively in the manner of a conscious thought. Zlopaša (2015) points out that the functions of the right hemisphere deal with emotional experiences and therefore influence the recognition of the imprinted, which implies they have a role in repressing and processing information. This would confirm somewhere in Freud's lifelong occupation with physiology.

In this paper, addressing the field of modern psychoanalysis from the perspective of science and pseudoscience, and the continued survival of psychoanalysis, the attitude of psychoanalysts themselves to this problem is striking.

Cozolino (2014), in the work of analyzing neurosciences, considers that neurological processing involves the unconscious. The preparation and organization of our experience is a filter that brings to consciousness what comes from the unconscious. A greater part of psychotherapy is considered with detecting, understanding and fixing the content, and the organization of those hidden layers. Most of the processes of evaluating the emotional coloring occur on the unconscious plane. Only a part is final and only the cognitive thought is conscious, which is a part of the synthetic function of the cerebral cortex. That would confirm Freud's life-long occupation with physiology. 
The instrument of professional (scientific) communication from Freud to this day, is a "Case report". They are good articles and reviews, which have a professional aspect and represent the gravity of acts well.

So far, we have followed the research in which the conditions of scientific work, sample, and description of the strategy of methodology research, as well as statistical techniques. Hereby the requirement of science and the requirement of verifiability are fulfilled. For case studies, this condition is elusive.

Obviously, much work was done in the $20^{\text {th }}$ and at the beginning of the $21^{\text {st }}$ century to demonstrate the scientific method in psychoanalysis.

The works of Stepansky \& Bornstain are very extensive and, most importantly, verifiable. Linking to neuroscience even enables neurophysiological measurement. One of the conditions of objective measurement is the existence of proven instruments and techniques of measurement, which has already been achieved in the neurological sciences. Some PET scanner devices, e.g. MR, also provide some CNS visualization. Modern receptor theories and the pharmaceutical lobby are forcing research into neuro-receptors and synapses.

\section{DISCUSSION}

In her work," Psychoanalysis and its paths", Élisabeth Roudinesco tries to defend the science of psychoanalysis. In the first instance, she turns to the works of Sokal and Bricmont, followed by their attempt to refute the science of Psychoanalysis by criticizing Lacan's work. Her report is quite extensive and what she presents in defense of psychoanalysis is the conclusion that the previously mentioned authors: "are both incapable of choosing and putting any piece of work they do not know to read and interpret into their context" (Roudinesco, 2005, pp. 93). What these critics resent is the fact that they, for many reasons, have taken the controversial work of Lacan as a platform for criticizing the whole of psychoanalysis. More interesting to us, however, is the second, more affirmative domain of her proof of the science of psychoanalysis. If we look into it more broadly, it greatly corresponds to the contemporary view of science. Specifically, since the second half of the twentieth century, the criterion of science has been the explanatory power and the power of prediction, not absolute coincidence with truth. In fact, even in the natural sciences, we cannot count on the absolute certainty of the hypotheses - there always remains the part that is accessible to further rational processing. It is even clearer in the domain of scientific revolution when "a dominant model is being doubted..." (Roudinesco, 2005, p. 95) and the whole focus of the research is changed. This often leads to the formation of new terminology and to the connection of something that was not considered in any way related until then. Bearing this in mind Roudinesco effectively puts Freud's psychoanalysis in relation 
to the whole stream of modern science, in the sense by which the mysteriously explained phenomena, e.g. dreams, he explains in a rational way.

So psychoanalysis has, since the emergence of Freud's interpretation of dreams, to this day, maintained the technique of understanding the unconscious and a valid range of technical instruments without which it is still impossible imagine therapy. It links it to neurophysiology where you can build certain scientific hypotheses. Many analysts believe that the therapeutic process does not exist without analyzing the patient's dreams that serve to understand the patient's unconscious. It was always impossible to understand the inner processes and the world of the unconscious without dreaming. Thus, the dream is a diagnostic instrument for both stability and resistance. A dream is also an insight into how the patient self-communicates with the object. That is why modern analysts are trying to save standard therapy procedures from the demands of the new age, which is the immanence to rush: as quickly and as quickly as possible, an approach that need not offer more effective results.

Today, psychoanalysts have been rebuked for the fact that standard therapy procedures have been the same for centuries, and even longer. Free association remains the basic method in psychoanalysis, and it might be for as long as psychoanalysis exists. It is the unit of process building. It is necessary to measure the efforts of both the patient and the therapist to reach an alliance in which they will always proceed in the same way and in the same place. So the instruments are still the setting and transfer, resistance, analyzability, interventions, countertransference, dream interpretation and achieving change.

These are the fundamentals of the existence of therapy in which the principle or main method is the free association of the patient. It can be said with certainty that: "The method of free joining gives fundamental context in which the analyst fights with the paradoxical clinical request that he or she be open to what the patient says, to what is new, to surprise, while at the same time handling the previous experience and theoretical models. Free Association supplies methodological structure in which the analyst struggles to keep the balance between involvement and observation, and between the focus on the past, current life and transfer. Free association is a method which enables patients to unify a task and explore their internal world, and work of their minds, with an interpersonal relationship with the analyst" (Aron, 1990, pp. 475). Then, on the same page, Aaron, says that replacing Freud's reflection method with an interpersonal presence does not mean that the patient's therapy was contaminated with the therapist's needs: "It is not my goal to adjust the patient to the therapist, but to tailor the therapy to the patient... My argument for the theory of two-membered or relational field should not be confused with the attempt to eliminate intra-psychics, negating the importance of fantasy and psychic reality or the centrality of bodily and childhood experience" (Aron, 1990, pp. 475). 
Certain changes in the understanding of the process in the twenty-first century are related to the partial abandonment of methods of reflection by interpersonal presence in therapy. This does not mean that the patient's contamination with the therapist's needs has occurred, but that it has been imposed as an opportunity for a new type of research. The problem Aaron has dealt with revolves around pulling metapsychology across a relational construct into a scientific framework where there are more than two subjects in therapy. In fact, here Aaron also introduces the analytic subject as a potential measure of research that would examine the a priori between two people. This immediately increases the ability to track analytics and transfers. This is important for future research, though certainly an intersubjective approach would be tuned to the nomothetical research and case reports. "In the mental life of an individual, someone else is constantly involved, as a model, as an object, as an assistant, as an adversary," and "in this extended, but quite justifiable sense of the word, social psychology is at the same time both within a contextual and intersubjective framework" (Aron, 1990, pp. 475).

Today, research focuses on the possibility of crossing different parameters and the ability to create a prospective study that would last for many years and capture different segments of the therapeutic process. Thus, it would be easier to fulfill the hypothetical character of the method's science, but also the possibility that such a theory would later be replaced by a theory of greater likelihood and greater scientific recognition. It is similar to neurophysiological research, e.g. the function of the cerebral cortex is considered through hypothetical theories and this would be the assumption that none of the brain impressions has failed. So the neurophysiological evidence of the unconscious exists as well as the evidence of suppression. Therefore, in neurophysiology, we have moved far ahead of Freud.

Finally, the question may be raised whether contemporary psychoanalysis would meet the scientific criteria and its capacity to perform research ventures.

The reviewed papers have been published in reputable journals and present many years of research into the connection between the practice and the theoretical corpus of psychoanalysis, as well as the creation of a suitable and scientific experiment. It has been shown that the publications discussed here are published in such journals that undergo quantitative and qualitative analyses.

The reproducibility of the results of the scientific work is complete, as each methodology, research procedures, statistical procedures and results are described in detail. These standard checks are satisfied, as well as the psychometric approach, which is also a requirement for measurements.

The scientific criteria are constantly growing and the corpus of knowledge must adapt to the new ones. The development of psychoanalysis 
is going in a good direction. Science is required not to endorse or market untested practices and products.

Jevremović (2010) is talking about the structure of the megalopolis of psychotherapy, where psychoanalysis is in the suburb. The danger of trivialization is great. Psychoanalysis is very serious and there is no compromise with any other forms of the inconceivable. That is why this rigor in patient selection and traditionality is perhaps the greatest sin, but also the value of psychoanalysis. What makes psychoanalysis always fresh is the work alliance, the supervisory work and the "let's think together." spirit. What makes it traditional is the respect for the patient's privacy, as well as his life without any return services. It is the rigorous and implacable abstinence rule since Freud.

\section{CONCLUSION ON THE PERSPECTIVES OF PSYCHOANALYSIS}

Contemporary psychoanalysis cannot be a science until it has completely rejected its subjectivity and begun to rely on empirical research experiences whose results are verifiable. Psychoanalysis should not be advertised, but it must come out of isolation and communicate with all the sciences, using all knowledge.

The corpus of psychoanalysis is impressive. The perspective of psychoanalysis is determined by the degree of the investment of society in science, as well as the development of educational systems that will enable the faster creation of experts. That would still be the path of psychoanalysis.

The road to science implies the continuous work with patients, as well as individual work. The patient and the therapist are an alliance. Their meeting makes sense of the events in both participants, certainly in the setting and in the life of therapy. The perspective of building a new relationship inevitably depends on that. It is considered that the problem today is not only the education of staff, which is inexorably long, but also the length of treatment.

Given that in reaching ourselves we embark on an adventure of the two, at the beginning or at the end of all the modalities the patient undergoes, the psychoanalytic method remains. Because psychoanalysis has balanced, all these years, between psychiatry and psychology, giving phenomena an expression of the interpretation of psychodynamics, it has fully explained certain illnesses and personality development, and can never be challenged.

\section{REFERENCES}

Aron, L. (1989). Dreams, Narrative and the Psychoanalytic Method. Contemporary Psychoanalysis, 25(1), 108-127.

Aron, L. (1990). One Person and Two Person Psychologies and the Method of Psychoanalysis. Psychoanalytic Psychology, 7(4), 440-475. 
Bornstein, R. F. (2001). The Impending Death of Psychoanalysis. Psychoanalytic Psychology, 18(1), 3-20. doi: 10.1037//0736-9735.I8.1.3

Bornstein, R. F. (2005). Reconnecting Psychoanalysis to Mainstream Psychology. Challenges and Opportunities. Psychoanalytic Psychology, 22(3), 323-340. doi: 10.1037/0736-9735.22.3.323.

Bornstein, R. F. (2007). Nomothetic Psychoanalysis. Psychoanalytic Psychology, 24(4), 570-590. doi: 10.1037/0736-9735.24.4.590.

Cozolino, L. (2014). The Neuroscience of Human Relationships: Attachment and the Developing Social Brain. WW Norton \& Company. Infant Mental Health Journal, 36(5), 533-535. doi: 10.1002/imhj.21532

Damjanović, A. (2015). Filozofska kritika kao nadogradnja psihoanalize (ili kako, kad i koliko filozofija priznaje frojdovo nesvesno) [Philosophical Critique as an Addition to Psychoanalysis (or How, When and How Much Philosophy Acknowledges Freud's Unconscious]. Engrami, 37(2), 41-53.

Dimitrijević, A. (2011). P E. Stepansky: Psychoanalysis at the Margins.Clinical Social Work Journal, 39(3), 321-322. doi: 10.1007/s10615-011-0323-8.

Dimitrijević, A. (2015). Being Mad in Early Modern England. Frontiers in Psychology, 6, 1-4. doi: 10.3389/fpsyg.2015.01740.

Fonagy, P. (2003). Psychoanalysis today. World Psychiatry, 2(2), 73. doi:10.1017/ s0954579497001399

Fonagy, P., \& Target, M. (1997). Attachment and reflective function: Their role in selforganization. Development and psychopathology, 9(4), 679-700.

https://www.bps.org.rs/psihoanaliza, (Pristupljeno decembra 2019)

https://www.hpsg.hr/psihonaliticari, (Pristupljeno decembra 2019)

Jalom, I. (2011). Gledanje u Sunce [Watching the Sun]. Novi Sad: Psihopolis.

Jandrić, A. (2017). Vitgenštajnova kritika Frojda [Wittgenstein's Critique of Freud]. Theoria 3, 60: 75-91. doi: 10.2298/THEO1703075C (Retrieved from 13 June 2019)

Jevremović, P. M. (2005). Ishodišta i putevi savremene psihoanalize [The starting points and pathways of contemporary psychoanalysis]. http://kud-logos.si/2005/ ishodista-i-putevi-savremene-psihoanalize/ (Retrieved from 13 June 2019)

Jevremović, P. M. (2010) Budućnost psihoterapije i pitanje vrednosti [Future of Psychotherapy and the Question of Value]. u: B. Ćorić (Prir.) Ljudi govore... [Peaple Talk...]. (str. 149-154). Beograd. FASPER.

Paris, J. (2017). Is Psychoanalysis Still Relevant to Psychiatry? The Canadian Journal of Psychiatry, 62(5), 308-312. doi: 10.1177/0706743717692306.

Roudinesco, E. (2005). Psihoanaliza i njezini putovi. [Psychoanalysis a and its pathways]. Zagreb: Naklada Slap.

Sandler, Dž., Dar, K., Holder, A. (1998). Pacijent i analitičar [The patient and analyst]. Beograd: Paideia.

Wallerstein, R. S. (2009). What Kind of Research in Psychoanalytic Science? International Journal of Psycho-Analysis, 90(1), 109-133. doi: 10.1111/j.17458315.2008.00107.x.

Zlopaša, S. (2015). Preduslovi kritike psihoanalize. [The Conditions of Critique of Psychoanalysis]. Engrami, 37(2), 55-62.

Zlopaša, S., Vuković, O., Dunjić Kostić, B. \& Damjanović, A. (2011). Psihoanaliza i Film [Psychoanalysis and Movie]. Engrami, 33(4), 61-69. 
138

\title{
САВРЕМЕНА ПСИХОАНАЛИЗА - ПЕРСПЕКТИВЕ И НАУЧНИ СТАТУС
}

\author{
Јана Милић* \\ Универзитет у Нишу, Филозофски факултет, Ниш, Србија \\ *Докторанд
}

\section{Резиме}

Кроз двадесети век утемељивао се корпус психоанализе. Многи угледни аутори припадници психоаналитичке школе настојали су да прилагоде научни метод и докажу да психоанализа даје резултате. Где је психоанализа данас и који је концепт приближава науци?

У овом раду се истичу савремена настојања да се психоанализа истраживачки повеже са неуронаукама. То даје одређену наду да се ефекат психоаналитичког метода може и забележити. Психоаналитичарима свакако можемо замерити херметичност на пољу објављивања достигнућа, али се од средине прошлога века ситуација мења. Постоји тенденција ка прављењу научне базе. С друге стране, научни критеријуми стално расту, те се постојећи корпус знања стално мора прилагођавати новим знањима, при чему је психоанализи замерано да се недовољно ради на томе. Данас се разматра могућност да се кроз неуронауку и номотетска истраживања постави биолошка, психолошка и социјална основа психоанализе. Многи угледни аналитичари су у току 20. века покушали да направе студије и стратегију за научну методологију психоанализе. Фонаги (1997) закључује да психоаналитичка пракса има дубока ограничења као облик истраживања, као и да се психоаналитичка теорија уопште може посматрати.

Модерна наука је готово искључиво интердисциплинарна. У ствари, у протеклих 15-20 година, област неуронауке брзо је напредовала. Фонаги (2001) сматра да је то право место за истраживање функционисања мозга и изражавање генетског потенцијала. Низ спроведених студија указао је на то да се утицај психотерапије може видети у променама у можданим активностима, користећи технике снимања мозга. Степански верује да би опоравак психоанализе био истински користан за друштво и науку у целини. Ако се ово не увиди, прети скрајнутост психоанализе. Степански каже да „,..опстанак професије у догледној будућности лежи иза кауча и изван просторије за консултације" (Димитријевић, 2011:312).

Покушај да се психоанализа повеже са науком и да коначно стане под психијатријски кишобран ослонио се на херменеутички начин размишљања, који се усредсређује на смислене интерпретације феномена, а не на емпиријско тестирање хипотеза и запажања. Оно што чини психоанализу свежом јесте радна алијанса, супервизијски рад „хајде да мислимо заједно”, затим и правило апстиненције и поштовање пацијентове приватности, као и његовог живота без икаквих повратних услуга. То ће увек остати обавезни део терапијског уговора, који је услов за даљи живот аналитичког пара. 